Available online on 15.03.2017 at http://jddtonline.info
Cournal of Drug Delivery and Therapeutics
$\begin{gathered}\text { 2011-17, publisher and licensee JDDT, This is an Open Access article which permits unrestricted } \\ \text { noncommercial use, provided the original work is properly cited }\end{gathered}$

Research Article

\title{
STUDIES ON ENDOPHYTES AND ANTIBACTERIAL ACTIVITY OF SAUSSUREA COSTUS (FALC.) LIPSCH
}

\author{
Anand Sagar, Vandana Chauhan and Ved Prakash* \\ Department of Biosciences, Himachal Pradesh University, Shimla-171005
}

\begin{abstract}
Different plant parts (root, stem, leaf) of Saussurea costus were used to isolate and investigate endophytic fungal species in summer, rainy and winter seasons. Total ten species of endophytic fungi belonging to seven genera (Aspergillus, Cunninghamella, Myrothecium, Penicillium, Pythium, Rhizopus and Trichoderma) were isolated from the root, stem and leaf in different seasons. The genus Aspergillus was found to be dominant with three species (A. nustus, A. wentii and A. niger). The genus Rhizopus was represented by two species ( $R$. oryzae and $R$. nigricans). The genera Cunninghamella, Myrothecium, Penicillium, Trichoderma and Pythium were represented by one species each i.e. Cunninghamella elegans, Myrothecium roridum, Penicillium chrysogenum, Trichoderma viride and Pythium sp. respectively. Antibacterial activity of root of $S$. costus has been investigated using different solvents (methanol, ethanol and acetone) at different concentrations $(25 \%, 50 \%, 75 \%$ and $100 \%)$ against three test bacteria namely $S$. aureus, E. coli and $Y$. pestis. Root extract of $S$. costus showed greater antibacterial activity using methanol as solvent followed by acetone and ethanol solvent. In case of methanol extract, maximum inhibition activity was shown against $S$. aureus and minimum against $E$. coli. Maximum inhibition was shown against $Y$. pestis and minimum against $E$. coli in case of acetone extract whereas ethanol extract exhibited highest inhibitory activity against $E$. coli and lowest against $Y$. pestis. Therefore, it is evident that $S$. costus exhibited antibacterial activity against all the test bacteria in all the solvents used in this study thereby conforming it as a good antibacterial agent for future study.
\end{abstract}

Keywords: Saussurea costus, endophyte isolation, antibacterial activity, agar well diffusion

Article Info

Received 03 Jan 2017; Review Completed 22 Jan 2017; Accepted 01 Feb 2017, Available online 15 March 2017

Cite this article as:

Sagar A, Chauhan V, Prakash V, Studies on endophytes and antibacterial activity of Saussurea costus (falc.) lipsch, Journal of Drug Delivery and Therapeutics. 2017; 7(2):5-10. DOI: http://dx.doi.org/10.22270/jddt.v7i2.1374

*Address for Correspondence

Ved Prakash, Department of Biosciences, Himachal Pradesh University, Shimla, India-171005, Email: vedp685@gmail.com, Mob: 9817872526

\section{INTRODUCTION}

Fungi are achlorophylous eukaryotic organisms which grow as single cell (yeasts) or as multicellular filaments (moulds/fungi), obtaining nutrition by absorption from their surroundings. Fungi play important role in the daily life of human beings such as in agriculture, food industry, medicine, textiles, bioremediation, natural cycling, as bio-fertilizer and in many other ways. Fungi are omnipresent on Earth, and represent essential components of many ecosystems where they are involved in many vital processes ${ }^{1}$.
Endophytic fungi are those which spend whole or part of their life-cycle colonizing inter-cellular or intracellular inside the healthy tissues of the host plants, typically causing no visible symptoms of disease. They play significant role and constitute a significant component of plant micro-ecosystems ${ }^{2}$. Endophytes occur in a wide variety of plant parts such as roots, stems, leaves, tubers, buds, ovules, seeds, fruits, xylem and bark. Among the host plants, medicinal herbs are one of the important groups of hosts for endophytic fungi ${ }^{3,4}$. Endophytes normally found in above ground plant parts, but also occasionally found in roots. 
Endophytes benefit the plant by increasing nutrient absorption, tolerance against stress, help in seed germination and also phyto-remediation of environmental pollutants 5 .

Plants contain many biologically active compounds, many of which show antimicrobial properties ${ }^{6}$. Plants are used as traditional healthcare in most parts of the world for thousands of years and there is increasing interest in plants as source of medicinal agents to fight microbial and fungal diseases ${ }^{7}$. Use of plant and its products has a long history. Plants produce a wide range of bioactive molecules, making them rich source of different types of medicine ${ }^{8}$. Secondary metabolites in plants include alkaloids, flavonoids, steroids, resins, fatty acids, tannins and phenolic compounds etc. Compounds extracted from different parts of the plants can be used in treatment of diarrhoea, dysentery, cough, cold, fever, bronchitis, cholera etc ${ }^{9}$.

Herbal medicines are more accessible to most of the population. About 60 to $85 \%$ of the population of every country of the developing world is dependent on herbal or native forms of medicine. The Himalayas have a great wealth of medicinal plants and traditional medicinal knowledge. Medicinal plants have played very important role in primary health care system among the local people of Himalayan region. Saussurea costus (Falc.) Lipsch. (Syn: Saussurea lappa C.B. Clarke family Asteraceae; Vern. Kuth) is commercially produced and well known medicinal plant of Indian Himalayan region which grows at an altitude of 2600 to $4000 \mathrm{~m}^{10}$.

This plant is endemic in India in the sub-alpine regions of Jammu and Kashmir, Himachal Pradesh and Uttaranchal, from an altitude of 3200-3800 m. The wild availability of this important plant is decreasing day by day due to over-exploitation for different medicinal and commercial purposes. This critically endangered medicinal plant species is enlisted in Convention on International Trade in Endangered Species of Fauna and Flora (CITES) and is one of the 37 Himalayan endangered medicinal plants that have been listed for in situ and ex situ conservation ${ }^{11}$.

Saussurea costus (roots and root oil) has become an important drug in the international market. In India, $S$. lappa grows naturally in Jammu and Kashmir while in Uttarakhand and Himachal Pradesh, the species is being cultivated since 1920 . Traditionally, S. lappa roots are used in the treatment of asthma, arthritis, chronic gastritis, dysentery, diarrhea, chronic skin diseases, fever, headache, abdominal pain and bronchitis ${ }^{12}$. Hence present study was undertaken on endophytes and anti bacterial activity of $S$. costus.

\section{MATERIALS AND METHODS}

\section{Plant material}

Keylong Headquarter (Lahaul and Spiti) of Himachal Pradesh was selected for the collection of study material named Saussurea costus (Falc.). The collection was made during summer, rainy and winter seasons. The material used for present study was root, stem, and leaf of Saussurea costus.

\section{Methodology for endophytic fungal isolation}

\section{(a) Hot water treatment}

The samples from the root, stem and leaf were taken and were washed in water at $60^{\circ} \mathrm{C}$ for fifteen minutes. Each sample was cut in three pieces and these were inoculated in separate Petri plates each containing PDA (Potato Dextrose Agar) medium which was supplemented with streptomycin $(150 \mathrm{mg} / \mathrm{l})$. These Petri plates were incubated at $25 \pm 2^{\circ} \mathrm{C}$ in incubator for one week. After the fungal growth in these plates, sub-culturing was done on PDA slants and the slants were preserved in refrigerator.

\section{(b)Three step method}

Firstly, samples were washed with sterilized distilled water. Then these were surface sterilized with $25 \%$ methanol for 5 minutes, followed by $50 \%$ methanol for 3 minutes and after that $75 \%$ methanol was used for 2 minutes. At last these samples were washed in sterilized water for five minutes. Inoculation of three pieces of each sample was then done on petriplates containing PDA medium supplemented with streptomycin. Petri plates were incubated at $25 \pm 2{ }^{\circ} \mathrm{C}$ for few days. The fungal colony growing in the petriplates were then transferred on PDA slants for sub-culturing.

\section{Maintenance and Preservation of Culture}

Maintenance of pure culture of different fungal genera was then done on PDA which was preserved in refrigerator. Sub-culturing was done at regular intervals in order to maintain cultures. Transfer of each fungal species from parent source to a fresh slant was done to maintain the pure cultures.

\section{Methodology for antibacterial screening}

\section{Maintenance and preservation of pure culture of bacteria}

Preservation of pure culture of all bacteria was done on nutrient broth and was kept in refrigerator. Subculturing was done at regular intervals.

\section{Preparation of root extract of Saussurea costus}

Fresh roots of $S$. costus were washed thoroughly for 4-5 times with tap water to remove dust and other foreign material from surface and then with $2 \%$ mercuric chloride. Then these were washed in distilled water for 2-3 times. Decantation of water from the material was then done. In order to dry out the material, it was kept in between the folds of filter paper. Plant material was weighed $50 \mathrm{~g}$, chopped into small pieces and with known volume of distilled water $(1: 1 \mathrm{w} / \mathrm{v})$; fine slurry of plant was prepared using sterile mortar and pestle at room temperature. To get the clear solution, it was then filtered with Whatman No. 1 filter paper. It was considered as $100 \%$ concentration.

\section{Methodology for antibacterial screening with root extracts of Saussurea costus}

Antibacterial screening was done using Agar well diffusion method. Nutrient Agar Medium (Beef extract 
$1 \mathrm{~g}$, Yeast extract 2g, Sodium chloride 1g, Peptone 5g, Agar 20g and distilled water $1 \mathrm{Lt}$.) was used throughout the investigation for the growth of microorganisms. The medium was autoclaved at $121.6^{\circ} \mathrm{C}$ for 30 minutes. The plates were left over night at room temperature to check for any contamination to appear. Bacteria were grown in nutrient broth for $24 \mathrm{~h}$. A $100 \mu \mathrm{L}$ nutrient broth culture of each bacterial species was used to prepare bacterial lawns. Nutrient agar plates were spread with $100 \mu \mathrm{L}$ of bacterial suspension. With the help of sterilized stainless steel cork bore, agar wells of $8 \mathrm{~mm}$ diameter were prepared. Five wells were prepared in agar plates. The wells in each plate were loaded with $25 \%, 50 \%, 75 \%$, $100 \%$ concentration with central well for control. The plates containing bacterial colonies were incubated at $37^{\circ} \mathrm{C}$ for 24 hours ( $S$. aureus, E. coli and Y. pestis) in an incubation chamber. All the tests were repeated in triplicates. Diameter of bacterial colonies of treatment and control sets was measured in mutually perpendicular direction on second day. Percentage inhibition of each bacterial species was calculated after subtracting the value of control from the value of extracts using control as standard ${ }^{13}$.

Percentage $(\%)$ of growth inhibition $=$ Control Test/Control $\times 100^{14}$

\section{RESULTS}

Ten species of endophytic fungi belonging to seven genera (Aspergillus, Cunninghamella, Myrothecium, Penicillium, Pythium, Rhizopus and Trichoderma) were isolated from root, stem and leaf of Saussurea costus during summer, rainy and winter seasons. The genus Aspergillus was represented by three species (A. nustus, $A$. wentii and $A$. niger). The genus Rhizopus was represented by two species i.e. $(R$. oryzae and $R$. nigricans). The genera Cunninghamella Myrothecium, Penicillium, Trichoderma and Pythium were represented by one species each i.e. Cunninghamella elegans, Myrothecium roridum, Penicillium chrysogenum, Trichoderma viride and Pythium sp. respectively (Table 1). Out of identified genera, four belonged to division Ascomycota, two belonged to Zygomycota and one belonged to Oomycota (Table 2). Further, maximum numbers of endophytic fungi were observed during rainy season followed by winter and summer (Table 3 ).

Table 1: List of endophytic fungi isolated from leaves, stem and root of Saussurea costus

\begin{tabular}{|c|c|}
\hline Sr. No. & Endophytic fungi isolated \\
\hline 1. & Aspergillus ustus \\
\hline 2. & Aspergillus niger \\
\hline 3. & Aspergillus wentii \\
\hline 4. & Cunninghamella elegans \\
\hline 5. & Myrothecium roridum \\
\hline 6. & Pythium sp. \\
\hline 7. & Penicillium chrysogenum \\
\hline 8. & Rhizopus oryzae \\
\hline 9. & Rhizopus nigricans \\
\hline 10. & Trichoderma viride \\
\hline
\end{tabular}

Table 2: Categorization of endophytic fungi from Saussurea costus into different divisions

\begin{tabular}{|c|c|c|}
\hline S. N. & Division & Genus \\
\hline 1. & Ascomycota & $\begin{array}{c}\text { Aspergillus, Penicillum, } \\
\text { Myrothecium, Trichoderma }\end{array}$ \\
\hline 2. & Zygomycota & Rhizopus, Cunninghamella \\
\hline 3. & Oomycota & Pythium \\
\hline
\end{tabular}

Table 3: Seasonal distribution of endophytic fungi isolated from Saussurea costus

\begin{tabular}{|c|c|c|c|c|}
\hline Sr.No. & Endophytic fungi isolated & Summer & Rainy & Winter \\
\hline 1. & Aspergillus ustus & - & + & - \\
\hline 2. & Aspergillus niger & + & + & + \\
\hline 3. & Aspergillus wentii & - & + & + \\
\hline 4. & Cunninghamella elegans & - & - & + \\
\hline 5. & Myrothecium roridum & + & - & + \\
\hline 6. & Pythium sp. & - & + & + \\
\hline 7. & Penicillium chrysogenum & + & + & + \\
\hline 8. & Rhizopus oryzae & - & + & + \\
\hline 9. & Rhizopus nigricans & + & + & + \\
\hline 10. & Trichoderma viride & - & + & - \\
\hline
\end{tabular}

Table 4: Antibacterial screening of methanol root extract of Saussurea costus against S. aureus, E. coli and Y. pestis

\begin{tabular}{|c|c|c|c|}
\hline \multirow{2}{*}{$\begin{array}{c}\text { Concentration } \\
(\text { In \%) }\end{array}$} & \multicolumn{3}{|c|}{ Percent inhibition of growth of test bacteria (mm $\mathbf{c}$ S.E.) } \\
\cline { 2 - 4 } & S.aureus & E.coli & Y.pestis \\
\hline 25 & $15.30 \pm 0.088$ & $14.33 \pm 0.088$ & $14.66 \pm 0.021$ \\
\hline 50 & $18.00 \pm 0.057$ & $17.00 \pm 0.057$ & $16.33 \pm 0.088$ \\
\hline 75 & $21.33 \pm 0.046$ & $20.33 \pm 0.021$ & $19.00 \pm 0.033$ \\
\hline 100 & $25.33 \pm 0.033$ & $22.00 \pm 0.033$ & $23.66 \pm 0.046$ \\
\hline
\end{tabular}

Each data point represents mean of three replicates \pm S.E. 


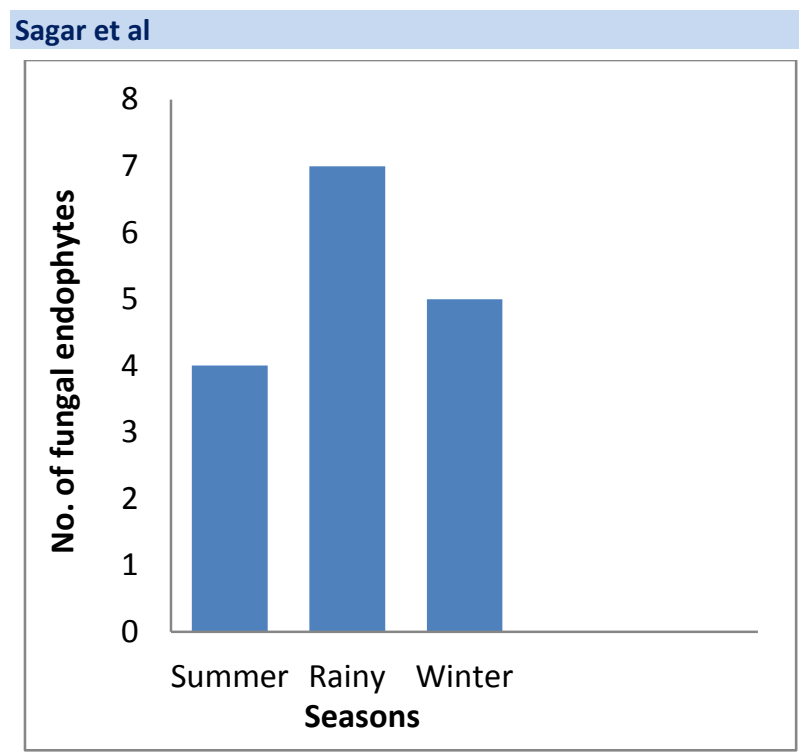

Figure 1: Histogram showing the seasonal distribution of different fungal endophytes isolated from different parts of Saussurea costus

Table 4 showing data pertaining to antimicrobial activity of methanol root extract of Saussurea costus at different concentrations. At $25 \%$ concentration, zone of inhibition recorded was $15.30 \mathrm{~mm}, 14.33 \mathrm{~mm}$ and $14.66 \mathrm{~mm}$ for $S$. aureus, E. coli and $Y$. pestis respectively. At $50 \%$ concentration, zone of inhibition recorded was 18.00 $\mathrm{mm}, 17.00 \mathrm{~mm}$ and $16.33 \mathrm{~mm}$. At $75 \%$ concentration, zone of inhibition recorded was $21.33 \mathrm{~mm}, 20.33 \mathrm{~mm}$ and $19.00 \mathrm{~mm}$. Maximum zone of inhibition was recorded at $100 \%$ concentration that was $25.33 \mathrm{~mm}$, $22.00 \mathrm{~mm}$ and $23.66 \mathrm{~mm}$ respectively.

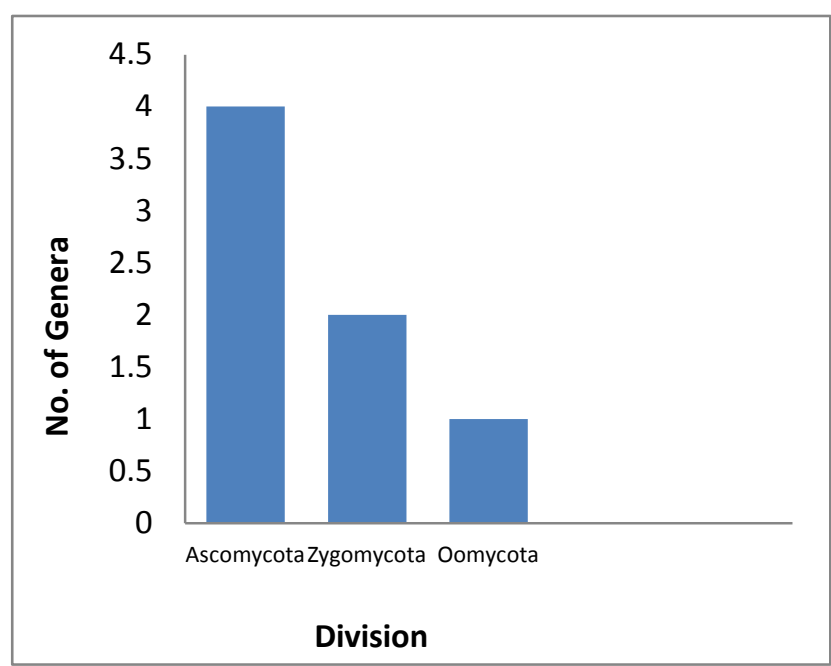

Figure 2: Histogram showing the distribution of different fungal endophytes isolated from different parts of $S$. costus into divisions

Table 5 showing data pertaining to antibacterial activity of ethanol root extract of Saussurea costus for S.aureus, E.coli and Y.pestis at different concentrations. At 25\% concentration, zone of inhibition recorded were 13.66 $\mathrm{mm}, 12.33 \mathrm{~mm}$ and $11.00 \mathrm{~mm}$ for $S$. aureus, E. coli and $Y$. pestis respectively. At $50 \%$ concentration, $15.66 \mathrm{~mm}$, $14.66 \mathrm{~mm}$ and $12.33 \mathrm{~mm}$ zone of inhibition were recorded. At $75 \%$ concentration, zone of inhibition recorded was $17.00 \mathrm{~mm}, 17.66 \mathrm{~mm}$ and $15.33 \mathrm{~mm}$. Maximum zone of inhibition was recorded at $100 \%$ concentration that was $19.00 \mathrm{~mm}, 19.66 \mathrm{~mm}$ and 17.66 $\mathrm{mm}$ respectively.

Table 5: Antibacterial screening of ethanol root extract of $S$. costus against $S$. aureus, E. coli and $Y$. pestis

\begin{tabular}{|c|c|c|c|}
\hline \multirow{2}{*}{$\begin{array}{c}\text { Concentration } \\
\text { (In \%) }\end{array}$} & \multicolumn{2}{|c|}{ Percent inhibition of zone of test bacteria (mm \pm S.E) } \\
\cline { 2 - 4 } & S.aureus & E.coli & Y.pestis \\
\hline 25 & $13.66 \pm 0.088$ & $12.33 \pm 0.033$ & $11.00 \pm 0.021$ \\
\hline 50 & $15.66 \pm 0.057$ & $14.66 \pm 0.021$ & $12.33 \pm 0.088$ \\
\hline 75 & $17.00 \pm 0.033$ & $17.66 \pm 0.088$ & $15.33 \pm 0.057$ \\
\hline 100 & $19.00 \pm 0.046$ & $19.66 \pm 0.057$ & $17.66 \pm 0.033$ \\
\hline
\end{tabular}

Each data point represent mean of three replicates \pm S.E.

Table 6: Antibacterial screening of acetone root extract of $S$. costus against $S$. aureus, E. coli and $Y$. pestis

\begin{tabular}{|c|c|c|c|}
\hline \multirow{2}{*}{$\begin{array}{c}\text { Concentration } \\
(\text { In \%) }\end{array}$} & \multicolumn{3}{|c|}{ Percent inhibition of growth of test bacteria (mm \pm S.E.) } \\
\cline { 2 - 4 } & S.aureus & E.coli & Y.pestis \\
\hline 25 & $13.66 \pm 0.033$ & $12.33 \pm 0.021$ & $13.33 \pm 0.088$ \\
\hline 50 & $15.33 \pm 0.057$ & $14.33 \pm 0.088$ & $16.66 \pm 0.057$ \\
\hline 75 & $18.66 \pm 0.088$ & $17.66 \pm 0.033$ & $18.66 \pm 0.021$ \\
\hline 100 & $22.33 \pm 0.046$ & $21.00 \pm 0.046$ & $20.33 \pm 0.046$ \\
\hline
\end{tabular}

Each data point represent mean of three replicates \pm S.E.

Table 6 showing data pertaining to antibacterial activity of acetone root extract of Saussurea costus for $S$. aureus, E. coli and $Y$. pestis at different concentrations. At $25 \%$ concentration, zone of inhibition recorded was $13.66 \mathrm{~mm}, 12.33 \mathrm{~mm}$ and $13.33 \mathrm{~mm}$ for $S$. aureus, E. coli and $Y$. pestis respectively. At $50 \%$ concentration,
$15.33 \mathrm{~mm}, 14.33 \mathrm{~mm}$ and $16.66 \mathrm{~mm}$ zone of inhibition was recorded. At $75 \%$ concentration, $18.66 \mathrm{~mm}, 17.66$ $\mathrm{mm}$ and $18.66 \mathrm{~mm}$ zone of inhibition was recorded. Maximum zone of inhibition was recorded at $100 \%$ concentration that was $22.33 \mathrm{~mm}, 21.00 \mathrm{~mm}$ and 20.33 $\mathrm{mm}$ respectively. 


\section{DISCUSSION}

Saussurea costus is an important medicinal plant of Himalayan region which helps in treating various diseases. Present investigation was carried out on $S$. costus with the objective of isolating and identifying its fungal endophytic species and antibacterial activity of root extract of this plant against three pathogenic bacteria (E. coli, S. aureus and Y. pestis)

\section{1) Endophytic fungi isolated from Saussurea costus}

In the present investigation, ten species of endophytic fungi belonging to seven genera (Aspergillus, Cunninghamella, Myrothecium, Penicillium, Pythium, Rhizopus and Trichoderma) were isolated from root, stem and leaf of Saussurea costus during summer, rainy and winter seasons. This could be attributed to the reason that environmental conditions greatly influence the occurrence of fungi in the plant ${ }^{15}$. Isolation of endophytes from various plant parts showed greater numbers of endophytes during rainy than winter and summer seasons.

Various workers have reported similar fungal endophytes from different plants. Sagar and Chauhan ${ }^{16}$ reported five fungal endophytic species belonging to four genera viz. Penicillium, Rhizopus, Gliocladium and Trichoderma from leaves, bark and root of Quercus leucotrichophora. Sagar and Kaur ${ }^{17}$ isolated four species of endophytic fungi (Aspergillus flavus, A.niger, Cephalosporium Acremonium, Gliocladium fimbriatum and Myrothecium sp.) from roots, bark and leaves samples of Aesculus indicia. Tejesvi et al ${ }^{18}$ investigated fungal endophytes from inner bark segments of some medicinal tree species viz Holarrhena antidysenterica, Butea monosperm and Crataeva magna, Azadirachta indica, and Terminalia chebula. Fusarium, Verticillium, Trichoderma, Chaetomium, Myrothecium and Pestalotiopsis species were identified from these tree species. Bzerra et $a l^{19}$ worked on Cactus (Cereus jamacaru) and identified 59 fungal species, of which $30.3 \%$ were sterile mycelia. Fungal species isolated were Cladosporium cladopsporioides, Aspergillus flavus, Trichoderma viride and Fusarium oxisporum. There is no previous report variable regarding endophyte isolation of S. costus.

\section{2) Antibacterial screening of root extract of Saussurea costus}

Result of antibacterial activity revealed that methanol extract showed greater zone of inhibition followed by acetone than ethanol. It has been found that with increase in concentration of root extract, zone of inhibition also increases. In case of methanol root extract maximum zone of inhibition recorded was 25.33 $\mathrm{mm}$ against S.aureus and minimum zone of inhibition was $22.00 \mathrm{~mm}$ against $E$. coli. In case of acetone root extract maximum zone of inhibition recorded was 22.33 $\mathrm{mm}$ against $S$. aureus and minimum zone of inhibition was $20.33 \mathrm{~mm}$ against $Y$. pestis. In case of ethanol root extract maximum zone of inhibition recorded was 19.66 $\mathrm{mm}$ against $E$. coli and minimum zone of inhibition was $17.66 \mathrm{~mm}$ against $Y$. pestis.

Alaagib and Ayoub $^{20}$ investigated antibacterial activity of root of Saussurea lappa using petroleum ether, chloroform, methanol and water extracts as solvents. It was revealed that chloroform extract showed the highest antibacterial activity. Chang et $a l^{21}$ also investigated ethanol extracts of $S$. lappa with various solvents ( $n$ hexane, chloroform, and $n$-butanol). The antimicrobial activity of $S$. lappa was examined against six food-borne pathogens (L. monocytogenes, B. cereus, B. subtilis, $S$. aureus, S. choleraesuis and V. parahaemolyticus) and also compared to that of the synthetic antibiotics. It is found that the $S$. lappa ethanol extract and $n$-hexane fraction have strong activity against $B$. cereus and $V$. parahaemolyticus strains compared to ampicillin against food-borne pathogens. Even though, present investigation are of preliminary type, yet they have established a base for further extension of this work towards isolation and purification of bioactive compounds present in this medicinal plant.

\section{CONCLUSIONS}

The results obtained in the present investigation indicated that fungal endophytic species were found in different plant parts of Saussurea costus. Number of endophytic species varies with different seasons and maximum number was investigated in rainy Seasons. Ten species of endophytic fungi belonging to seven genera (Aspergillus, Rhizopus, Myrothecium, Penicillium, Pythium and Trichoderma) were isolated. The genus Aspergillus was dominant with three species. Antibacterial activity of root extract of $S$. costus showed greater activity using methanol as solvent followed by acetone and ethanol.

\section{ACKNOWLEDGEMENT}

Thanks are due to The Chairperson, Department of Biosciences Himachal Pradesh University Summer Hill, Shimla (HP) India for providing all the facilities to carry this research work.

\section{CONFLICT OF INTEREST}

The authors hereby declare that there is no conflict of interest regarding the manuscript and experimentation done. 


\section{REFERENCES}

1. Dighton J, White JF, Oudemans P, The Fungal community, its organization and role in the ecosystem, 2005, 3rd edn. CRC Press, Boca Raton, FL

2. Tan RX, Zhou WX, Endophytes as rich source of functional metabolites, Nat. Prod. Rep, 2001, 18, 488-459.

3. Yan ZY, Luo J, Guo XH, Zeng QQ, Screening of ginkgolides-producing endophytic fungi and optimal study on culture condition, Nat. Prod. Res. Dev, 2007, 19, 554-558.

4. Xu LJ, Zhou LG, Zhao JL, Jiang WB, Recent studies on the antimicrobial compounds produced by plant endophytic fungi, Nat. Prod. Res. Dev, 2008, 20, 731-740.

5. Reis VM, Baldani JI, Baldani VLD, Dobereiner J, Biological dinitrogen fixation in gramineae and palm trees, Critical Reviews in Plant Sciences, 2008, 10, 227-247.

6. Cowan MM, Plant product as antimicrobial agents, Clin. Microbiol. Rev, 1999, 12, 564-582.

7. Charlandy CM, Seaforth CE, Phelps RH, Pollard GV, Khambay BPS, Compounds produced by plant endophytic fungi, Nat. Prod. Res. Dev, 1999, 20, 731-740.

8. Nair R, Kalariya T, Chanda S, Antibacterial activity of some selected Indian medicinal flora, Turk. J. Biol, 2005, 29, 4147.

9. Joshi B, Sah GP, Basnet BB, Bhatt M, Sharma D, Subedi K, Pandey J, Malla R, Phytochemical extraction and antimicrobial properties of different medicinal plants: Ocimum sanctum (Tulsi), Eugenia caryophyllata (Clove), Achyranthus bidentata (Datiwan) and Azadirachta indica (Neem), J. Microbiol. Antimicrob, 2011, 3, 17.

10. Shah R, Nature's medicinal plants of Uttaranchal: Herbs, Grasses and Ferns, Nanital, Uttarakhand, India, 2006, Gyanodaya Prakashan.

11. Kuniyal CP, Rawat YS, Oinam SS, Kuniyal JC, Vishvakarma SCR, Biodiversity Conservation, 2005, 14, 1035-1045.
12. Kala CP, Manjrekar N, Ethnomedicobotany of Indian Trans Himalaya: A case study from Spiti, Journal of Econonomic and Taxonomic Botany, 1999, 23, 177-183.

13. Hemashenpagam N, Selvaraj T, Antimicrobial potential of different extracts of Solanum xanthocarpum Chard and Wendt, Plant Archives, 2010, 1, 387-390.

14. Kannan P, Ramadevi SR, Hopper W, Antibacterial activity of Terminalia chebula fruit extract, African Journal of Microbiology Research, 2009, 3, 180-184.

15. Subhramanyam A, Ecology and distribution, Thermophilic moulds in Biotechnology (Eds. Johri BN, Satyanarayana T, Olsen J), Kluwer academic Pub. Netherlands.1990, 13-42.

16. Sagar A, Chauhan S, Study on fungal associates of Quercus leucotrichophora, J Pure Appl Microbiol, 2009, 3, 357-362.

17. Sagar A, Kaur R, Study on fungal associates of Aesculus indica, Biological Forum-An International Journal, 2010, 2, 49-52.

18. Tejesvi MV, Mahesh B, Nalini MS, Prakash HS, Kini KR, Subbiah V, Shetty HS, Fungal endophyte assemblages from ethno pharmaceutically important medicinal trees, Can. J.Microbiol, 2006, 52, 427-435.

19. Bezerra JDP, Santos MGS, Barbosa RN, Svedese VM, Lima DMM, Fernandes MJS, Gomes BS, Pavia LM, AlmeidaCortez JS, Souza-motta CM, Fungal endophytes from Cactus cereus in Brazilian tropical dry forest: A first study, Symbiosis, 2013, 60, 53-63.

20. Alaagib RMO, Ayoub SMH, Studies on the chemical composition and antibacterial activity of Saussurea lappa (Asteraceae), The Pharma Innovation Journal, 2015, 4, 73-76.

21. Chang KM, Choi SI, Chung SJ, Kim GH, Antimicrobial activity of Saussurea lappa C.B. Clarke Roots, Food Sci Nutr, 2011, 16, 376-380. 